\title{
SUSTAINABLE DEVELOPMENT CITY-BEACH IN ALICANTE
}

\author{
L. ARAGONÉS ${ }^{1}$, J. GARCÍA-BARBA ${ }^{1}$, Y. VILLACAMPA ${ }^{2}$, I. LÓPEZ ${ }^{1}$, M.E. GÓMEZ-MARTÍN ${ }^{1}$ \& \\ J.I. PAGÁN ${ }^{1}$ \\ ${ }^{1}$ Department of Civil Engineering, Alicante University, Spain. \\ ${ }^{2}$ Department of Applied Mathematics, Alicante University, Spain.
}

\begin{abstract}
Tourism development in recent decades has involved a large urban development in coastal areas, with different anthropogenic structural interventions on the coast such as the construction of commercial buildings and marinas, which has led to intense erosion and large imbalances in the last century. This situation also affects the city of Alicante, with the area between the port of Alicante and the Huertas Cape, one of the most depressed areas of the city, due to various actions carried out since the 70s, for anthropic example fillers for building marinas, jetties and broken in poor condition because they are made of sandstone, and a bad connection between the two parts of the city. In this work the creation of a new promenade that communicates both zones is proposed, creating new beaches eliminating anthropogenic fillings and the remains of breakwaters along the coast, the union of diverse marine area in one marina, and the insertion of an artificial reef multipurpose. With all this it is to improve the attraction of the area, and increase the mobility of the city on the coast.
\end{abstract}

Keywords: anthropogenic elements, beaches, mobility, tourism, urban development.

\section{INTRODUCTION}

Coastal tourism began in the nineteenth century and has increased nonlinearly since then, spurred by a combination of developments in transport technology and increased prosperity. Initially, it was mainly national, but the introduction the low-cost air transport, ferries and cruise ships caused an exponential increase of international tourism between 1950 and the beginning of XXI [1]. Worldwide the number of international arrivals has shown a steady increase from 25 million in 1950 to over 700 million in 2002, corresponding to an average rate of $6.6 \%$ annually and is estimated to be 350 million in 2020 tourists visiting the coastal region of the Mediterranean [2].

Tourism development unplanned and poorly managed can damage the natural environment, but the overall understanding of the interaction between tourism and the environment in particular in coastal areas is quite poor, with debates about the impacts of tourism development often they try to generalities instead of the results of scientific research into the effects of tourism in a given environment or a specific species [3]. Minerbi [4] highlighted some of the environmental impacts of tourism: (i) the resorts and golf courses increase environmental degradation and pollution. (ii) Littering has taken place on the beaches and viewpoints and parks. (iii) Exploitation of marine sanctuaries. (iv) Interference hydrological cycles by resorts, changing patterns of underground waters and participating in over-extraction of groundwater.

On the other hand, the resorts require efficient transport connections. The explosion of tourism based on the car and the bus, in the twentieth century, has contributed greatly to the 
development of extensive networks of roads throughout the developed world, increasing habitat loss against the asphalt and the increased habitat fragmentation [1]. Many coastal roads were built simply to connect tourist centres and increasing tourism opportunities. The resorts are also characterized by its large parking area, still occupy more land, especially in coastal areas [5].

The large passenger ships showed a decline in importance during the 1960s and 1970s after being the premier mode ocean freight for about a century [6]. However, the last 30 years have seen a revival of passenger traffic, with the growing success of cruises [1]. Cruise tourism has become significant for a number of ports because cruise tourists are higher yield tourists, spending, on average, much higher amounts per day than other categories of international tourists $[7,8]$.

A priori, leisure-related activities associated with tourism, and the infrastructural and transport arrangements associated with them, should take place within a biologically sustainable framework that minimises environmental deterioration and loss of ecological function and services. Unfortunately, the inherent conflict between 'biologically sustainability' and 'economically sustainability' is almost never resolved in favour of the former [9].

The aim of this work is perform an urban and sustainable performance in the coastal area of the city of Alicante which is in a high state of degradation by anthropogenic activities undertaken during the period under review, so that it gets recreated, giving it a ground continuity the promenade which aims to make citizens and tourists from Alicante to walk and enjoy the views and the temperate climate of the sea. It is intended to concentrate the three marinas into one and create new beaches protected by several breakwaters and a multifunctional artificial reef (MFAR) improving recreational activities and therefore the economy of the area. And improve mobility and road connection along the entire coastal stretch.

\section{STUDY AREA}

Alicante is a port city located southeast of the Mediterranean coast. The economic activities of this city have historically been geared to trade, stressing the importance of its port. For this reason, the port occupies much of the coastal front of the city. However, since the 1950s, tourism has increased in importance, and is currently a major tourist city. Its climate is dry Mediterranean, with mild temperature throughout the year and little rain concentrated in equinoctial periods. The average annual temperature is slightly above $18^{\circ} \mathrm{C}$ (reference period: 1981-2010; AEMET). Winters are mild. The coldest month (January) has a mean temperature of $11-12^{\circ} \mathrm{C}$, a maximum of about $17^{\circ} \mathrm{C}$ and a minimum $6-7^{\circ} \mathrm{C}$ (AEMET). These mild temperatures are perfect for strolling along the coast throughout the year.

The resident population in Alicante is 328,648 inhabitants [10], which is increased during the summer season thanks to its tourist offer based on its historical heritage, its leisure and its beaches. The city has 81 hotels and inns as well as 3 apart, as well as several apartments. Water sports have always been present, with strong demand for moorings for pleasure boats. North of the harbour are the beaches of the La Almadraba, La Albufereta, la Serra Grossa and Postiguet (Fig. 1). This area is currently much degraded due to various anthropogenic activities carried out during the years $70-80$. Over $5.2 \mathrm{~km}$ of coastline are three marinas, two of them built and one under construction (now interrupted). In addition, they are suffering erosion of beaches is significant, affecting the buildings.

\section{CURRENT PROBLEMS}

Then the various problems encountered in the study area, distinguishing between the following four areas are presented: 


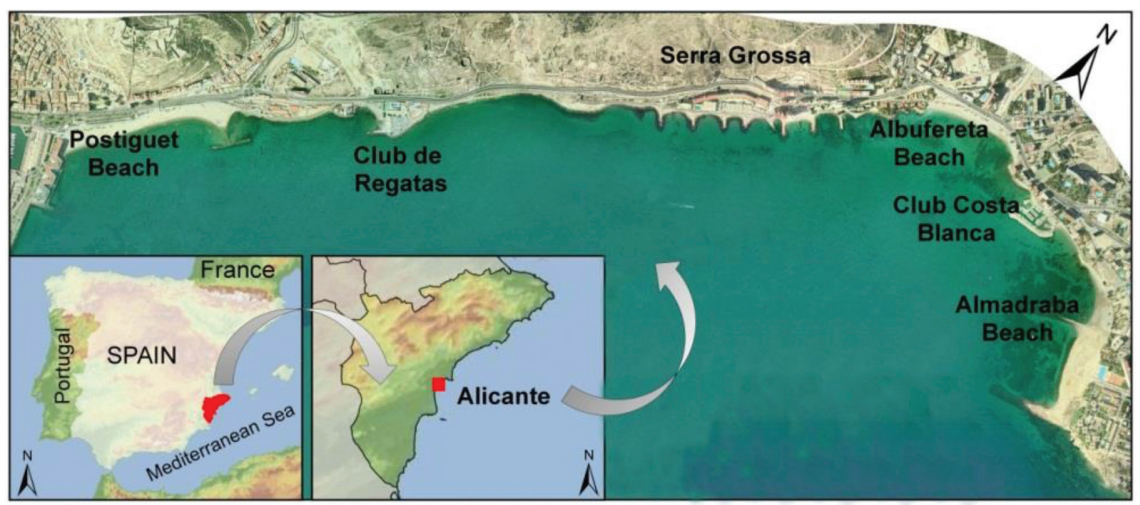

Figure 1: Location of the study area and its different parts.

Almadraba beach area: This coastal area has undergone major changes between 1956 and 2009 due to major maritime works have been carried out. First is the construction of the Club Costa Blanca, which has generated a separate physiographic unit which prevents longitudinal transport which has caused the tilting of the beach leaning on the jetty of the port. Secondly, the construction of the marina of Puerto Amor, whose construction began in 1980, for which he was required to land from the sea (Fig. 2a) win, therefore, a new waterfront was generated, from a fine beach width filling one large debris (Fig. 2b). The construction of this port was interrupted by disagreements among government agencies and so has continued until today.

Albufereta beach zone: This beach has a clear trend of material loss, having lost between 1956 and $200716 \mathrm{~m}$ wide beach (Fig. 2c), which has been corrected by various contributions of sand from different parts of Alicante area (dredging of the port (2008 and 2012), excavations in the TRAM tunnel prior screening (2012)). In the north, next to the marina Costa Blanca we found a large gap between the beach and boardwalk (Fig. 2d). Also south of this area, very close to the area of peaks of the Serra Grossa, there are a large number of houses that once were within the Maritime Terrestrial Public Domain (MTPD), and therefore was scheduled for demolition, but because the new Coastal Law (2014), these houses are no longer in this situation and therefore have to provide them with the necessary equipment and the necessary access.

Serra Grossa area: This area has changed substantially between 1956 and 2009, which is due to the actions carried out in 1980, by which gained ground rising sea surface to be had in 1956. To give attraction to this area, beaches were protected by a field perpendicular piers on the coast (Fig. 2e and f), which consisted of stone sandstones were generated which has caused wear in just 40 years and therefore their movement by wave that has crippled the beaches protected. Because of these harsh actions, the plan shape of the coast has remained intact over the years. However, the coastal area has been degraded due to the breakwaters, buildings and industrial parks located in this area. On the other hand, access to this area is via a one-way road and no parking area also has a large gap between the promenade and the beach, so it is very difficult to access for users the bathroom area.

Postiguet beach area: Figure $2 \mathrm{~g}$ and $2 \mathrm{~h}$ show of this area due to the execution of a breakwater parallel to the coast, which protects it from wave action. Also, drainage channel rainwater pouring directly on the beach next to Club de Regatas is found. On the other hand between the 


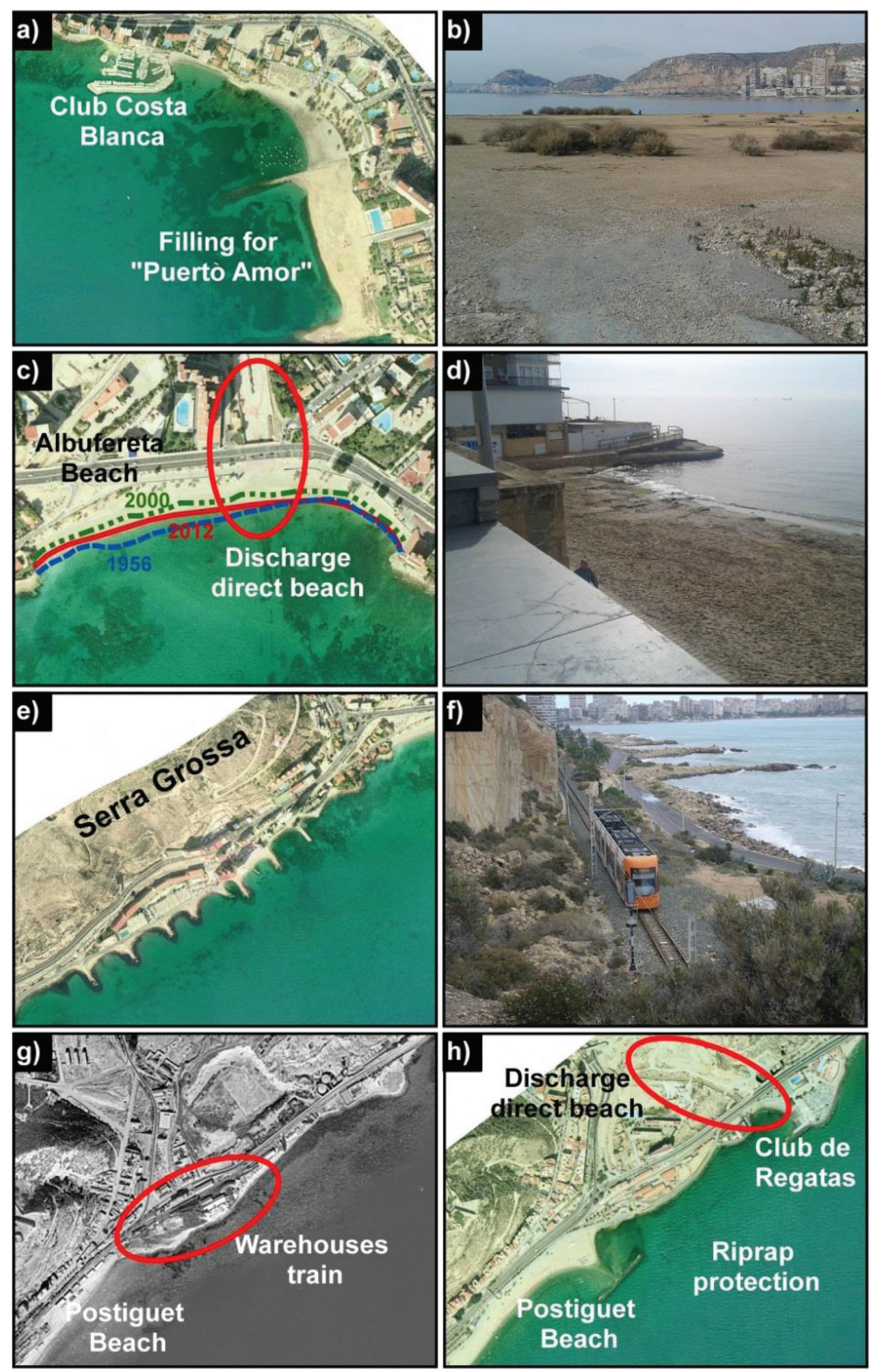

Figure 2: Evolution and current status of the study area.

Club de Regatas and Postiguet beach find the ancient train station warehouses (now obsolete), the area is protected by breakwater causing wave reflection generating currents which cause erosion north of the tombolo, and the accumulation of sand inside the Club of Regatas.

\section{PROPOSED SOLUTIONS}

As is evident from the previous section, the area has undergone a great urban development inland has caused various problems on the coast, so the need for action is set, carrying a sort 
of traffic as well as provide a new promenade between the beaches of Postiguet and Albufereta. Thus, improving mobility in the area as the connection of the entire coastal front north of Alicante between the two beaches, eliminating as far as possible the existing slopes, so can reach the beach of Postiguet and therefore the centre of the city from any point on the coast by any means without having to overcome excessive unevenness.

The promenade adapts throughout its length to the beach that will be executed in the area. Thus, the pedestrian area is achieved, which is currently very poor and will be a very attractive for pedestrians to the achievement of the works space. Next to the strip of waterfront are designed and adapted for road traffic in ways that enhance the accessibility battered the area. Road traffic allows solving accessibility and vehicle movements in this area through the implementation of four pavilions linked between both by unidirectional or bidirectional roads of approximately $3.5 \mathrm{~m}$ per lane depending on the specific section (Fig. 3). Furthermore, as the area is intended to be a new attraction for people accessibility is completed with the execution of 115 parking spaces divided into two distinct sections (Fig. 3a).

The clarity of route is obtained with a linear concise idea ride a bike lane marked by $1.5 \mathrm{~m}$ wide element next to plantations has to have complete continuity from start to finish. Also they are provided at various green zones than the existing trees on the fringe of walk with aesthetic reason and attraction for people.

The tour of the promenade is designed conditioned by the existing railway platform. As soon the new tram line 3 will open through the Marina tunnel, this platform will be deprecated, so one of the main objects of the project is the use of the platform for plotting the ride and the road to traffic. In addition, it will be used as a greenway adapted from the promontory of Rocafel to Albufereta beach at Sol Naciente (Fig. 3).

On the promontory of Rocafel one of the four roundabouts planned will run. One of its branches out, in this case meaning Alicante, use the existing tram tunnel in this case adapting the road to the elimination of the railway platform and providing it with the asphalt and lighting required by traffic regulations. On the other hand, in the branch outlet in the direction San Juan, has projected a bridge with superior, tied arch, 75 meters span between supports (Fig. 4). The definition of this unique structure has been made to serve connecting the seafront projected between the beaches of Postiguet and Albufereta with the Villajoyosa Avenue northeast and is visually appealing to the user of the projected beaches (Fig. 3a). At the same time, enhancing the landscape of the coastline and saving the greenway where the railway platform will be transformed.

The actions in the maritime area are based on three important points: (i) design and relocation of a new marina where existing unify, (ii) Creation of new beaches along the entire study

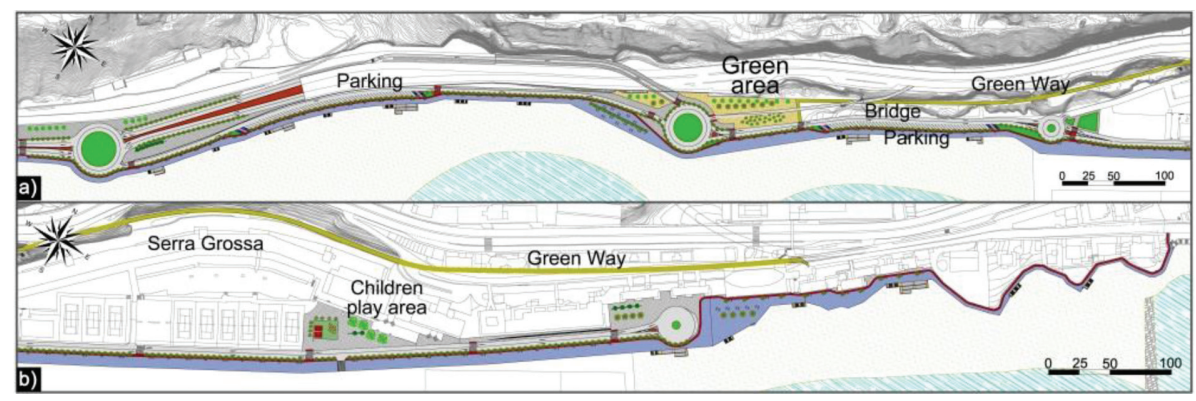

Figure 3: Plant new path and promenade. 
area and (iii) inserting a MFAR to improve the leisure activities of the area while protecting the shore wave.

To design the new port, a study of demand for moorings and type of vessels in the Levant has made, concluding that the new marina to dispose of 1,500, which should be designed to serve to vessels between 6 and $30 \mathrm{~m}$ in length. Subsequently, following the guidelines set by ROM 3.1-99 and RD 2/11, each of the different elements that make up the New Marina have been designed and calculated (Fig. 5). For construction, reusable material from the demolition of Club Costa Blanca and Club de Regatas will be used, and filler for the construction of Puerto Amor, which will be relocated to this new marina located in front of the current Serra Grossa beach, giving solution to the problem of sea in the area and the concession for the construction of Puerto Amor.

For the generation of new beaches, the execution of works of defence and containment will be required to be stable in the long term, which serves to reduce the incoming waves to the area, as well as serve as a barrier to the longitudinal transport. Thus, the problem is solved in the area, notably promoting tourism, and likewise, to the town's economy.

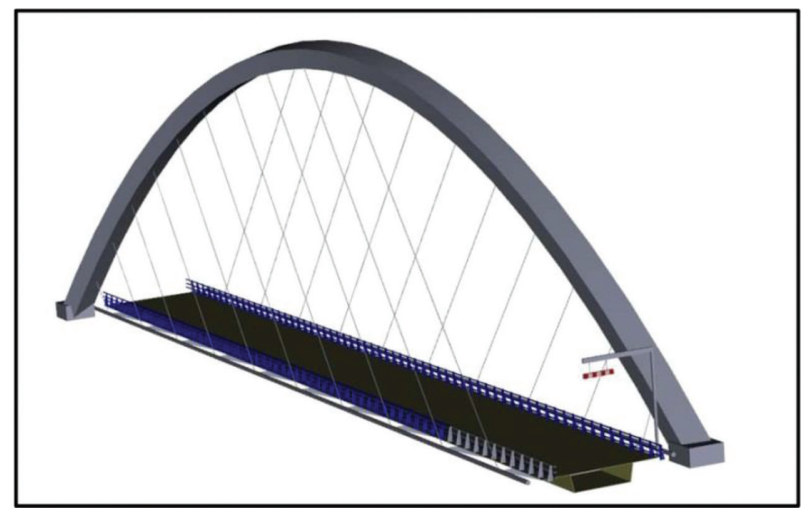

Figure 4: Overview of the new bridge.

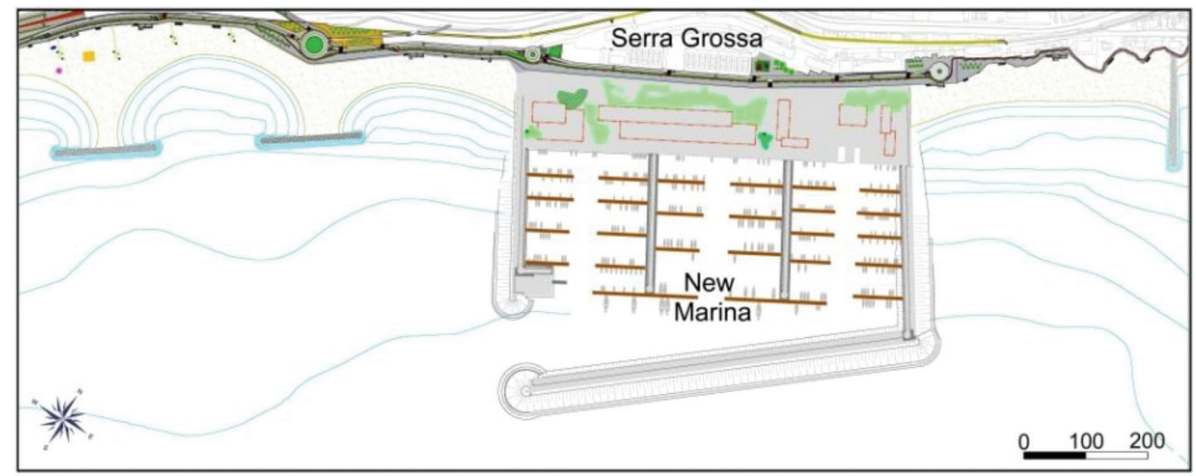

Figure 5: Design beach plant located north and south of the new marina. 
The design of the beach north of the present Club de Regatas is shown in Fig. 5. North of the new marina, the beach will be supported by the south breakwater of the marina and north implementation will require one breakwater, which abut the Albufereta beach, taking containment function and support for the new beach.

In the south, the construction of two breakwaters that protect the beach from the storms, as well as serving to support it, together with the breakwater marina wrap arises. Its main function, besides serving as temporary support and protection, will reduce the ability of potential sediment transport wave, thus allowing creating a stable long-term beach. The waterfront has been defined using the criterion of maintaining a minimum dry beach width of about $40 \mathrm{~m}$, and is governed by the model of Hsu et al. [11], taking into account the average wave energy flow for each physiographic unit. To determine the position and size of the levees have been used criteria of Garberí et al. [12], and Berenguer and Enríquez [13].

South of Club de Regatas, beach arises following the same design as in the north for the linearity of the beach, so breakwaters were held but one of them is replaced by an artificial reef for multipurpose one hand act as a breakwater protecting the area and creating a small hemitombolo and secondly improve conditions for surfing in the area so as to promote the development of flora and fauna in the area. To design MFAR has followed the methodology proposed by López et al. [14]. In the area, we also find the output channel drain rainwater, which is currently discharged directly on the beach (Fig. 2). To solve these problems, two perpendicular breakwaters will run at the waterfront of $170 \mathrm{~m}$ in length to serve as lateral support of the beach and warm the channeling the Goteta channel, and the depth that would reach -3.5. As will be part of the beach, and to avoid as much as possible so the visual impact will be partially overtopping. Finally, the existing breakwaters will be dismantled and will be located further south along the alignment, size and spacing as the levees designed to provide greater rigidity and stability to the beach (Fig. 6).

In the northern area between the beaches of Almadraba and Albufereta, as already said the Club Costa Blanca will be demolished and south breakwater and stuffing made for the construction of Puerto Amor will be retired. The northern breakwater of Puerto Amor will be repaired so that it can provide support for the new beach. The south breakwater of Club Costa Blanca to serve as a second foothold for the beach will expand. Finally according to the dynamics in the area, an exempted breakwater to protect the new beach in the area (Fig. 7) will be built. Figure 7 shows how will be the new beach near Puerto Amor and comparing the current situation in the North of Alicante bay and the proposal made in this paper.

Once the new beach designed, currents and sediment transport have been studied by module Mopla of the SMC program, to determine the behaviour of the new waterfront facing a temporary, studying all directions incident wave. It has also proved the effectiveness of MFAR, ensuring that the necessary current four cells are generated according Ranasinghe et al. [15] to the accretion of the beach is generated.

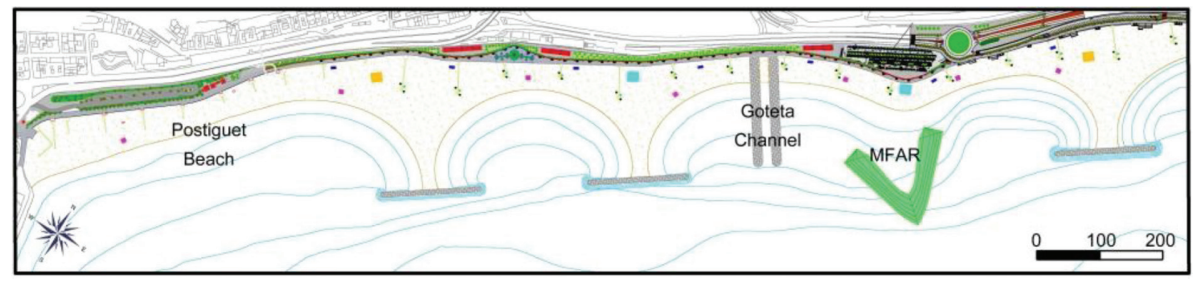

Figure 6: Design beach plant located south of the current Club de Regatas. 


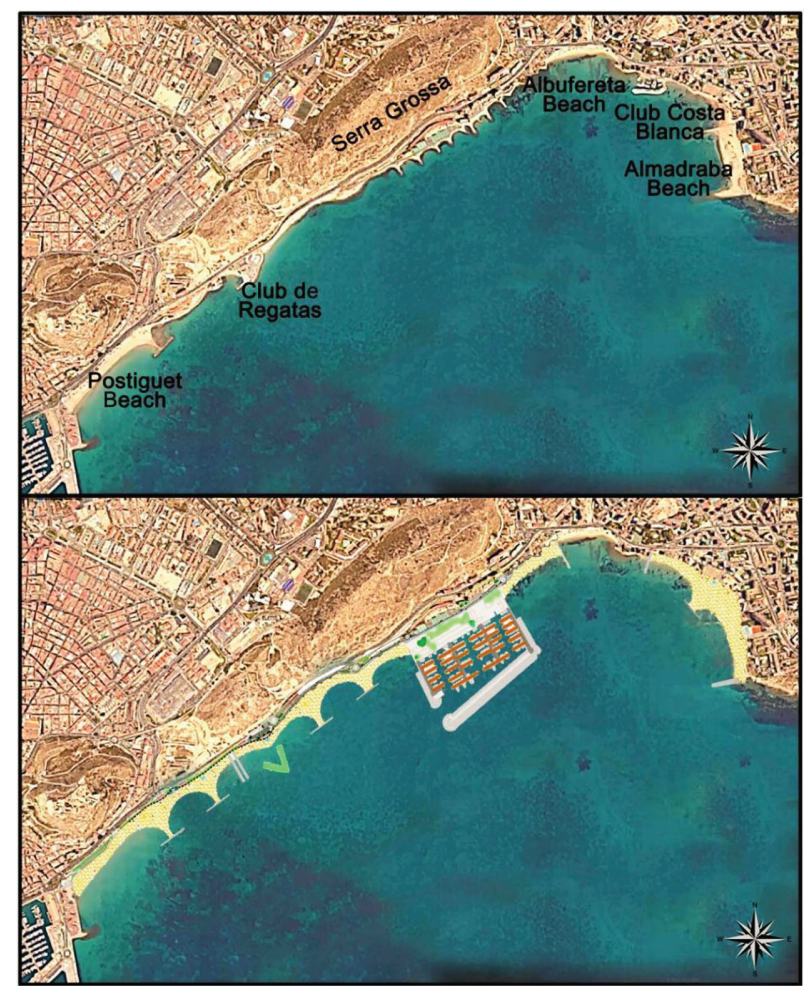

Figure 7: Comparison between the current situation and the proposed design.

\section{CONCLUSION}

Alicante is a city in which there have been many anthropogenic structural interventions on the coast such as the construction of buildings and marinas, which has led to an intense degradation of the coastal area, which has produced serious imbalances in the last century. In the 70s, he began the urban development of the city along its coastline. Thus, in the coastal area north of Puerto de Alicante to the Almadraba beach, there is one of the most depressed areas of the Alicante coast. In this area of only $5.2 \mathrm{~km}$, there are three marinas (Club de Regatas, Club Costa Blanca and Puerto Amor under construction since 1980 and paralyzed at present), the direct discharge of storm water on the beaches of Albufereta and next to the Yacht Club, buildings facing the Serra Grossa formerly were within the MTPD and therefore must have been demolished, but with the new Coastal Law (2014) this is no longer true, and therefore should be equipped with the necessary equipment and access for residents and the construction of $1 \mathrm{~km}$ of breakwaters that were built in the 70s for a beach in front of the aforementioned buildings.

This study has made a proposal for coastal and sustainable urban development so that the current problems are resolved. For this, mobility in the area and communication between the two ends of the city have been improved eliminating as far as possible existing unevenness by a promenade between the Postiguet and Albufereta beach. Along the promenade road link has been proposed in which is located several parking spots (currently nonexistent), various green and recreational areas and a greenway. It has turned the connection of this new road to the existing road by a suspension bridge $75 \mathrm{~m}$, to serve as a tourist attraction and singular point for the city. Furthermore, the union of the three marinas proposed area into one drawing 
as possible materials dismantling thereof. Finally, throughout the area will create new beaches and a MFAR in front of the old warehouses of the train, so that the leisure area is increased and thus the economic activity of the same.

\section{ACKNOWLEDGEMENTS}

The authors thank Dirección General de Costas (Ministerio de Agricultura y Medio Ambiente) and University of Alicante for providingaccess to their data.

\section{REFERENCES}

[1] Davenport, J. \& Davenport, J.L., The impact of tourism and personal leisure transport on coastal environments: a review. Estuarine, Coastal and Shelf Science, 67(1-2), pp. 280-292, 2006.

http://dx.doi.org/10.1016/j.ecss.2005.11.026

[2] WTO. World Tourism Organisation, 2004 [cited 2014 07.02], avalible at http://www. world-tourism.org/facts

[3] Hall, C.M., Environmental impact of tourism in the Pacific. Tourism in the Pacific: Issues and Cases, pp. 65-80, 1996.

[4] Minerbi, L., Impacts of Tourism Development in Pacific Islands: Department of Urban and Regional Planning, University of Hawaii at Manoa, 1992.

[5] Burak, S., Dog`an, E \& Gaziog lu, C., Impact of urbanization and tourism on coastal environment. Ocean \& Coastal Management, 47(9-10), pp. 515-527, 2004.

http://dx.doi.org/10.1016/j.ocecoaman.2004.07.007

[6] Ritter, W. \& Schafer, C., Cruise-tourism. Tourism Recreation Research, 23(1), pp. 6571, 1998.

http://dx.doi.org/10.1080/02508281.1998.11014821

[7] Dwyer, L. \& Forsyth, P., Economic impacts of cruise tourism in Australia. Journal of Tourism Studies, 7(2), p. 36, 1996.

[8] Dwyer, L. \& Forsyth, P., Economic significance of cruise tourism. Annals of Tourism Research, 25(2), pp. 393-415, 1998.

http://dx.doi.org/10.1016/S0160-7383(97)00098-4

[9] Hall, C.M., Trends in ocean and coastal tourism: the end of the last frontier? Ocean \& Coastal Management, 44(9), pp. 601-618, 2001. http://dx.doi.org/10.1016/S0964-5691(01)00071-0

[10] INE. Instituto Nacional de Estadística. 2015, avaliable at http://www.ine.es/

[11] Hsu, J.R.C., Silvester, R. \& Xia, Y.M., Generalities on static equilibrium bays. Coastal Engineering, 12(4), pp. 353-369, 1989.

http://dx.doi.org/10.1016/0378-3839(89)90012-4

[12] Garberí, L.B., Valdecantos, V.N. \& González, J.D., Parámetros geométricos de diques exentos en el litoral catalán. Ingeniería Civil, 147, p. 2007, 2001.

[13] Berenguer, J. \& Enríquez, F., Evaluación metodológica. Impacto Ambiental de un Puerto, CEDEX, 1987.

[14] López, I., Tinoco, H., Aragonés, L. \& García-Barba, J., The multifunctional artificial reef and its role in the defence of the Mediterranean coast. Science of the Total Environment, 550, pp. 910-923, 2016.

http://dx.doi.org/10.1016/j.scitotenv.2016.01.180

[15] Ranasinghe, R., Larson, M. \& Savioli, J., Shoreline response to a single shore-parallel submerged breakwater. Coastal Engineering, 57(11-12), pp. 1006-1017, 2010. http://dx.doi.org/10.1016/j.coastaleng.2010.06.002 